\title{
How Do Second-Generation Immigrant Students Access Higher Education? The Importance of Vocational Routes to Higher Education in Switzerland, France, and Germany
} Jake Murdoch*, Christine Guégnard*, Dorit Griga**, Maarten Koomen***, and Christian Imdorf***

* IREDU / Céreq, University of Bourgogne Franche-Comté, FR-21000 Dijon, jake.murdoch@ubourgogne.fr and christine.guegnard@u-bourgogne.fr.

** SFIVET / Department of Sociology of Education, University of Bern, CH-3052 Zollikofen / CH3012 Bern, dorit.griga@ehb-schweiz.ch.

*** Institute of Sociology / TREE, University of Bern, CH-3012 Bern, maarten.koomen@soz.unibe.ch and christian.imdorf@soz.unibe.ch.

\section{Abstracts \\ How Do Second-Generation Immigrant Students Access Higher Education? The Importance of Vocational Routes to Higher Education in Switzerland, France, and Germany}

We analyse the access to different institutional pathways to higher education for second-generation students, focusing on youths that hold a higher-education entrance certificate. The alternative vocational pathway appears to compensate to some degree, compared to the traditional academic one, for North-African and Southern-European youths in France, those from Turkey in Germany, and to a lesser degree those from Portugal, Turkey, Ex-Yugoslavia, Albania/Kosovo in Switzerland. This is not the case in Switzerland for Western-European, Italian, and Spanish youths who indeed access higher education via the academic pathway more often than Swiss youths. Using youth panel and survey data, multinomial models are applied to analyse these pathway choices.

Keywords: Second-generation, access, higher education, pathways, international comparison

Wie gelangen Jugendliche der zweiten Generation an die Hochschule? Die Relevanz berufsbildender Hochschulzubringer in der Schweiz, Frankreich und Deutschland

Wir untersuchen die Zugänglichkeit unterschiedlicher institutioneller Pfade zur Hochschule für Jugendliche der zweiten Generation und konzentrieren uns dabei auf Jugendliche mit einer Hochschulzugangsberechtigung. Der alternative berufsbildende Pfad scheint den traditionellen akademischen Weg für nordafrikanische und südeuropäische Jugendliche in Frankreich, für türkische Jugendliche in Deutschland, aber auch für portugiesische, türkische, exjugoslawische sowie (kosovo)albanische Jugendliche in der Schweiz bis zu einem gewissen Grad kompensieren zu können. Dies gilt jedoch in der Schweiz nicht für westeuropäische, italienische und spanische Jugendliche, die die Hochschule vergleichsweise häufiger als Schweizer Jugendliche über den akademischen Pfad erreichen. Zur Analyse der Wahl verschiedener Hochschulzugänge mit Jugendpanel und -surveydaten wurden multinomiale Regressionsmodelle verwendet.

Schlüsselwörter: Zweite Generation, Zugang, höhere Bildung, Bildungspfade, internationaler Vergleich

\section{Accès des immigrants de deuxième génération à l'enseignement supérieur : prégnance des} parcours professionnels en Suisse, France et Allemagne

Nous analysons l'accessibilité des jeunes d'origine immigrée de deuxième génération à l'enseignement supérieur via différents parcours scolaires dans trois pays, en nous focalisant sur ceux qui possèdent un diplôme permettant l'accès aux études supérieures. Le parcours professionnel alternatif favorise la poursuite d'études supérieures dans une certaine mesure, par rapport à la voie traditionnelle ou académique, pour les jeunes en France originaires d'Afrique du Nord et d'Europe du Sud et, à un moindre degré, pour ceux en Allemagne originaires de Turquie, et ceux en Suisse originaires du Portugal, de Turquie, d'ex-Yougoslavie et de l'Albanie/Kosovo. Ce n'est pas le cas en Suisse pour les jeunes originaires d'Europe occidentale, d'Italie et d'Espagne qui en fait accèdent davantage aux études supérieures par la voie scolaire académique que les jeunes Suisses. A partir des données de panels et d'enquêtes auprès des jeunes, des modèles de régression sont utilisés pour analyser ces choix de parcours.

Mots-clés: Deuxième génération, accès, enseignement supérieur, parcours, comparaison internationale 


\title{
How Do Second-Generation Immigrant Students Access Higher Education? The Importance of Vocational Routes to Higher Education in Switzerland, France, and Germany
}

\author{
Jake Murdoch*, Christine Guégnard*, Dorit Griga** , Maarten Koomen***, \\ and Christian Imdorf***
}

Over the past decades, educational policy measures in Switzerland, France, and Germany have introduced vocationally orientated programmes at upper secondary level that can grant access to higher education. These measures are geared to attenuate some of the well-known inequalities in the education system by improving the educational attainments of disadvantaged groups such as students from low socio-economic families or those with a migrant background. In this article, we wish to clarify through which pathway second-generation immigrant students who have obtained a higher education entrance qualification, access higher education and to what extent the education system channels and fosters or hampers this access. We have chosen Switzerland, France, and Germany because they have implemented different pathways to higher education. Differences in the education systems in Switzerland, France, and Germany may account for varying educational successes of second-generation immigrants.

Pathways to higher education are especially relevant in educational systems that are highly stratified, such as those of Germany and Switzerland (Bol and Van de Werfhorst 2013). France, in contrast, has a more comprehensive general secondary school system, followed by a stratified postsecondary system encompassing academic or vocational programmes. General or academic education in France is, thereby, much more prestigious than vocational education. In contrast, following a vocational programme is a much more viable option in Switzerland and Germany, and it can be prestigious to the degree of being on par with obtaining general or academic credentials. For the total population, the share of an age cohort who attains a baccalaureate level diploma (ISCED 3A respectively Matura/Maturité,

IREDU / Céreq, University of Bourgogne Franche-Comté, FR-21000 Dijon, jake.murdoch@ubourgogne.fr and christine.guegnard@u-bourgogne.fr.

** SFIVET / Department of Sociology of Education, University of Bern, CH-3052 Zollikofen / CH-3012 Bern, dorit.griga@ehb-schweiz.ch.

*** Institute of Sociology / TREE, University of Bern, CH-3012 Bern, maarten.koomen@soz.unibe. ch and christian.imdorf@soz.unibe.ch. 
Baccaléauréat and Abitur) is around a third (30\%) in Switzerland, half (49\%) in Germany, and over half (53\%) in France (OECD 2014). ${ }^{1}$ Moreover, there is generally a strong link between tracking in secondary school and binary (academic and vocational programmes and institutions) higher education structures (Switzerland and Germany being good illustrations), opposed to comprehensive secondary school and diversified higher education systems (e.g. United States, Japan and Korea). France is a mix type of systems with both a binary higher education system and late tracking (Arum et al. 2007).

In addition, while the three countries display considerable variation in terms of immigration policy, they all have a sizeable second-generation immigrant population, large parts of whom do experience obstacles in their educational and professional careers (Heath et al. 2008; Becker 2011; Hupka and Stalder 2011; Brinbaum and Guégnard 2013). Youths with a migrant background typically exhibit increased educational aspirations but they are often also at a disadvantage in stratified school systems. Vocational pathways to higher education might thus prove helpful to migrants in order to facilitate their educational aspirations. Hence, on an institutional level, the article aims at identifying the educational pathways that foster access to higher education for second-generation immigrant students in these three countries.

In the following sections, we will briefly introduce the education system of each country. We pay particular attention to new vocational pathways to higher education (section 2). The second-generation and their educational achievement are presented in section 3 where we also conceptualise how students with a migrant background access higher education. Section 4 introduces the national data sets and our strategy for analysis. The findings of multivariate analysis are presented in section 5 , and section 6 concludes the paper.

\section{Educational routes to higher education in Switzerland, France, and Germany}

In Switzerland, two out of three students that finish compulsory education at age 15 enrol in some form of vocational education and training (VET) that typically last between three and four years. Only one out of five students enrol in general baccalaureate schools (called Gymnasium) to receive an academic baccalaureate (Matura, maturité), granting the student access to higher education institutions - to universities in general, or, after an additional year of work experience, to a university of applied science. The second main access to higher education apart from the Gymnasium is the Federal Vocational Baccalaureate (Berufsmaturität, maturité professionnelle). It

1 The lower ratio of baccalaureates in Switzerland compared to Germany goes hand in hand with a higher offer of vocational education and training (VET) in the Swiss case (Buchholz et al. 2012). The different VET offers may be due to different national economies with lower unemployment rates in Switzerland compared to Germany, resulting in a higher willingness of Swiss companies to offer apprenticeship places. 
was implemented in the mid-1990s in order to adjust the Swiss education system to the Bologna reform and to stimulate transition from upper secondary VET to higher education (Nikolai and Ebner 2012). The Federal Vocational Baccalaureate can be obtained after graduation from basic VET training at upper secondary level and grants access to the newly created Universities of applied sciences. The opportunity to obtain a Federal Vocational Baccalaureate is strongly linked to certain (academically more demanding) training professions.

In France, unlike in Switzerland, the Baccalauréat is the standard final diploma of upper secondary education as far as the gateway to higher education institutions is concerned. There are two particularly important decision stages in the secondary system. The first occurs at the age of 15 at the end of lower secondary (college), where the choice is between lycée général (academic baccalauréat) and technologique, and lycée professionnel as the vocational tracks. The second arises when students are 18 years old and concerns access to higher education in different types of programmes (Universities, short vocational programmes and elite prep schools). The latter has expanded considerably as a result of the increasing number of students in secondary education, the increasing number of baccalauréat holders and the high social demand for training. Another measure that has increased the access to higher education is the creation of a vocational baccalauréat in 1985, which offers new opportunities, particularly to children of working-class or immigrant families. After the end of lower secondary school, youths can first follow a short school based vocational course for two years (certificat d'aptitude professionnelle - CAP / brevet d'études professionnelles - BEP) and then enrol in the baccalauréat professionnel for two years.

In Germany, the dominant route to higher education is via the Abitur which can be obtained at the Gymnasium. The share of youths obtaining the Abitur thereby differs by federal state. With $34 \%$ of one cohort the minimum is represented by Bavaria, while the maximum share of $53 \%$ can be observed in North Rhine-Westphalia. At the end of the fourth school year, - based on their performances - students receive their school-recommendations, and are thus tracked, into the Gymnasium, the Realschule or - depending on the federal state - the Hauptschule. Subsequent secondary stage is thereby divided into the Orientierungsstufe and Mittelstufe (lower secondary) and the vocational system, vocational schools (Berufsfachschule), technical secondary schools (Fachoberschule), occupational Gymnasiums (berufliches Gymnasium), upper vocational schools (Berufsoberschulen), as well as traditional Gymnasiums (upper secondary). Lower secondary education thereby finishes with the attainment of the Hauptschulabschluss or mittlere Reife (Realschulen). The latter thereby enable students to pursue their educational careers at the Gymnasium. One aspect in lower secondary stage often discussed is the early separation and tracking of students since it can be regarded the main reason for many changeovers in the system as well as a high degree of social selectivity. As regards upper secondary 
education, many grammar-school leavers enrol in vocational education afterwards, which involves that they traverse this part of secondary stage twice.

Based on the mentioned alternatives to the Gymnasium, one alternative entrance certificate to higher education is the subject-bounded entrance certificate to universities (fachgebundene Hochschulreife) which can be attained at occupational grammar schools, upper vocational schools (Berufsoberschulen), some vocational schools (Berufffachschule), specialised academies (Fachakademie) as well as vocational and study colleges. Moreover, the entrance certificate to universities of applied sciences exists (Fachhochschulreife). It enables students to enter a university of applied sciences and broadly equates to access-rights related with the Swiss Berufsmaturität. It includes an academic and professional part. It can be attained at different institutions for example at technical secondary schools (Fachoberschule) and can also be awarded to students who left upper secondary education and who gained some professional experience. Also for entrance to universities of applied sciences an additional certificate grants subject-bounded access (fachgebundene Fachhochschulreife). For example, it can be attained at technical secondary schools (Fachoberschule) and to some extent at occupational Gymnasiums (berufliches Gymnasium).

\section{Second-generation youths, educational achievement and access to higher education}

\subsection{Second-generation population}

As in many other European countries, the migration flow into Switzerland has changed over time. Today, the second-generation is made up of the offspring of both "new-arrivals" (Turks and former Yugoslavs from outside EU; Portuguese from EU) and an older second-generation, the offspring from traditional low-skilled labour migrants ("guest-workers") from the sixties (Italians and Spanish) (Fibbi et al. 2011). This second generation forms an important part of the young population of the country. A third of the resident population aged 15-24 has a migratory background and more than two thirds of children and youth with a residence permit belong to the second- and third-generation (FSO 2008). Italians and former Yugoslavs represent the largest groups, followed by Portuguese and Turks (Fibbi et al. 2011).

In France the proportion of second-generation immigrants is one of the highest in Europe amongst the total population. This is particularity due to a long history of labour migration and the links with its former colonies. After 1945, the rebuilding process in France started a migration stream of workers from Algeria and later from other North African countries. Simultaneously, the economic and political climate in Italy, Spain and Portugal, led towards emigration flows from these countries into France. During the 1970s, four out of five migrants living in France came from either Spain, Italy, Portugal, Algeria, Morocco or Tunisia. Today, the second-generation 
accounts for $11 \%$ of the total population (Bouvier and Breem 2014). About a third of the second-generation has Spanish, Italian or Portuguese roots, and another third comprises those of North African origins. Like in Switzerland, this population is very young. More than a third are under 18, compared to just under a quarter for those without a migrant background.

As far as Germany is concerned, its economy has been dependent on immigrant workers ever since the 1950 s post-war boom. Although the majority of these "guest workers" have now returned to their home countries in South and Southeast Europe, many have stayed in the country - as did many of the Turkish immigrants who came after them. This has resulted in Germany gradually developing from a country that accommodated "guest workers" to a country with regulated immigration. Repatriates of German descent, who for generations have been living in the states of the former Soviet Union, Romania and Poland, are a second major group of immigrants. The population with a migrant background (both foreign-born or those with a parent born in a foreign country) accounts to $20 \%$ or 16.5 million individuals (Statistisches Bundesamt 2015). Amongst the latter group, Turkish immigrants represent the largest sub-group (18\%), followed by immigrants from the former Soviet Union (17\%), former Yugoslavia (9\%), Poland (9\%), Italy (5\%), and Greece (2\%) (Pape 2010; Hossmann and Karsch 2011).

\subsection{Educational attainment of the second-generation}

In Switzerland, with a participation rate of $13 \%$ in baccalaureate schools (SCCRE 2011), foreign nationals (a category containing both first and some of the secondgeneration youth) are considerably underrepresented in schools granting the traditional higher education entrance qualification (the average participation rate being 20\%). However, first- and second-generation Italian and Spanish students display similar school performances to their Swiss peers. In comparison, students with a Turkish, former Yugoslav, or Portuguese background, perform much worse. With regard to secondary education in Switzerland, youths from France, Germany and Austria enrol most frequently in baccalaureate schools (36\%), followed by Swiss students (24\%), and youth from Italy and Spain (18\%). The second-generation Turks, former Yugoslavs, and Portuguese have the lowest enrolment into baccalaureate schools (10\%) (FSO 2008).

In France the democratisation of education has not reduced the obstacles created by social inequalities when it comes to accessing higher levels of education. From a cohort of pupils who start secondary school together, 64\% of native French obtain the Baccalauréat (which enables access to higher education). This figure varies greatly for youths of immigrant origin: only a third of Turkish origin, over half of those of North and sub-Saharan African origin and with Portuguese roots, and finally two thirds (67\%) for those from Asian descent obtain the Baccalauréat (Vanhoffelen 2013). Moreover, relative to their French counterparts those of North 
African origin are less likely to obtain a general baccalauréat and more likely to acquire a vocational one, as a result of their school performance and of the tracking process that deviates them from their initial aspirations (which are similar to French natives) (Brinbaum and Guégnard 2013).

In Germany, immigrant youths enrol less often into more demanding secondary school-types, e.g. Gymnasium, and they are overrepresented at less demanding secondary schools, e.g. Hauptschulen and Förderschulen. Different origin groups further perform better than others do. When compared to Italians or Turkish youths, Eastern Europeans, for example, do comparatively well in the German educational system (BAMF 2008).

\subsection{Theorizing higher education access for second-generation youths}

Cross-national variability of students with a migration background accessing higher education raises the question to what extent national educational structures influence educational and social mobility of vulnerable immigrant groups. Well-known factors affect the chance of access to higher education - such as language, social background, educational aspirations, immigrant selection, and gender - and may interact with characteristics of the education system (Crul et al. 2012; Heath and Brinbaum 2014). Different countries may have different curricula in place for language support, and local language skills may matter differently as academic selection criteria. Language skills might be particularly hindering for students with a migrant background in school systems that place pupils into different types of secondary schools early in their educational careers (such as in Switzerland or Germany). In contrast, in comprehensive school systems students with a migration background have more time to overcome such barriers (in our case France would come closest). Early tracking may also enhance the socially selective distribution of pupils in the different types of secondary schools. Such a mechanism would add to the relevance of language skills for early school selection where students with a migrant background are also from a socially unprivileged background. Griga and Hadjar (2014) provide evidence that low-stratified secondary school systems improve the probability of students with a migrant background and low social origins to attain a higher education degree, and that a stratified secondary school system likewise reduces their respective chances.

Finally, the characteristics of the education systems may also mediate the effect of educational aspirations on educational successes. Choice-driven and comprehensive school systems will be advantageous for youths with a migrant background because they are more likely to realise their increased educational aspirations (Heath and Brinbaum 2014). Comparative findings on access to higher education by nonimmigrant and immigrant students in Switzerland and France by Griga et al. (2013) indeed show that once students obtain an upper secondary certificate granting access 
to higher education, the chances of enrolling in higher education may be even higher for students with a migrant background if social origin is controlled for.

Parental socio-economic position explains a large proportion of the educational disadvantages of students with a migrant background (Heath and Brinbaum 2014). To capture the effect of the socio-economic position on educational inequalities, many studies use the concept of primary and secondary effects of social origin (Boudon 1974). This approach considers both (material and socialised) resources and decision-making in terms of subjectively expected utility and cognitive rationality. According to the approach of Boudon, primary effects of social origin are educational differences that result from socially biased performance levels that originate from class-specific differences in parental support and learning environments at home. Whereas primary effects explain why members of the lower socioeconomic classes perform less well in school, secondary effects of social origin refer to the inequalities associated with the choices of the students and their parents when controlling for social origin and previous school performance.

In recent work, the concept of primary and secondary effects on social origin has also been extended to that of migrant origin (Kristen and Dollmann 2010). Although primary effects of migrant origin, e.g. in the form of language barriers, may explain the disadvantages of migrant youths encountered in earlier transitions (Becker et al. 2013), no such effects seem realistic when considering the selective group eligible for higher education. Rather, if the focus is on educational branching points associated with student choice, the literature points to arguments indicating that educational decisions of youths with a migration background are subject to positively directed secondary effects of migrant origin. Studies that have focussed on educational transitions while controlling for socioeconomic status and performance, have found increased transition propensities into academically more demanding educational tracks for many migrant groups of disadvantaged social origins (Griga 2014). To explain the increased transition rates, several studies in the United States (Kao and Tienda 1995; Kao and Tienda 1998), France (Brinbaum and Cebolla-Boado 2007) and the Netherlands (Van de Werfhorst and Van Tubergen 2007) have shown that students of migrant origin exhibit comparatively higher educational aspirations.

In the empirical part of this article, we will use the concepts of educational pathway to analyse educational careers of youths and to draw a comparison between Switzerland, France and Germany. Following the proposition of Griga and Hadjar (2014) to consider alternative routes to higher education when analysing migrant students' higher education access, we are primarily interested to what extent policies designed to increase enrolment in higher education - particularly programmes aiming at fostering transition from upper-secondary VET tracks to higher education - affect access to higher education. We ask whether second-generation students use the same pathways to higher education in the three countries as students without a migration background. Previous research has shown that youths of North African 
origin in France benefit from these alternative vocational pathways to higher education whereas it is not the case for those of Turkish and former Yugoslav origin in Switzerland (Murdoch et al. 2014). The present article seeks to look further by addressing the situation of various second-generation immigrant groups both in France and Switzerland, and not only the ones covered by the previous study. Moreover, we wish to expand the analysis to Germany.

Because of different education traditions, it is likely that "vocationalised" pathways to higher education will affect students differently in each country. In Switzerland, the creation of the Federal Vocational Baccalaureate (FVB), or Berufsmaturität, created a new route to higher education and "academized" vocational education. We expect that second-generation students choose FVB less often compared to their Swiss peers as their parents might be less familiar with the Swiss VET system than with the academic route to access higher education (Glauser 2015). France has witnessed a vocationalisation of the academic route to higher education through the implementation of a specifically vocational orientated track. Even though second-generation youths have a preference for the academic pathway in upper secondary education (general baccalauréat), we expect them to be diverted towards the vocational one because of competitive disadvantages with regard to their academic skills and credentials. As for Germany, alternative vocational tracks such as the Fachabitur may help second-generation youths access higher education.

\section{Data}

We use panel data from Switzerland (Transitions from Education to Employment TREE), France (Panel d'élèves DEPP 95), and Germany (DZHW 2002) to analyse the accessibility of higher education through different educational tracks, comparing students with and without a migrant background. In our analysis, we are focusing on particular, nationally relevant, groups of second-generation students. In each country, we analyse the population that is eligible to study in higher education, i. e. those who have obtained a baccalaureate level diploma (respectively Matural Maturité, Baccaléauréat, or the Abitur). In the three countries, these youths entered higher education between 2002 and 2005.

The Swiss Transitions from Education to Employment (TREE) study is a PISA2000 follow-up survey, consisting of a nationally representative sample (panel) of students leaving compulsory school after the $9^{\text {th }}$ grade. TREE has surveyed nine times the youths from 2001 to 2014 through their educational career. From the TREE data, we take a subsample of first- and second-generation youths from Western and Southern European origin (735 individuals), from Turkey, former Yugoslavia, 
Albania/Kosovo ${ }^{2}$, and Portugal (678), and we compare these two groups with a sample of students who have at least two Swiss-born parents (4386).

The French DEPP (Direction de l'évaluation, de la prospective et de la performance) panel was collected by the Ministry of Education and consist of a nationally representative sample of students who entered the first year of secondary school (17830 youths) from 1995 and were followed until 2005. They were surveyed through lower secondary (collège), upper secondary (lycée) and subsequent higher education. We compare the educational pathways of first- and second-generation students from North African origin (494 individuals from Algeria, Morocco, or Tunisia) and those from Southern Europe (132), with the educational trajectories of French students with two native French parents (8983).

The German Studienberechtigten-Panel 2002 (Deutsches Zentrum für Hochschul- und Wissenschaftsforschung - DZHW) is a panel survey in which schoolgraduates entitled to higher education were surveyed twice (2002 and 2005), enabling us to analyse educational careers of youth after the completion of upper secondary education. In contrast to the Swiss and French data, the German data does not include the specific countries of birth of the students and their parents and we are therefore forced to use the student's nationality. In the German analysis, we compare the pathways of Eastern European (100 individuals) and Turkish youths (86) with their native German counterparts (11868).

Using multinomial logistic regression, we will analyse how having a migrant background predicts placement in different educational pathways to higher education. In consecutive models we control for schooling characteristics (previous individual school performance, e.g. grades, reading skills and competency test) and social characteristics (parental educational background, and educational/job aspirations). Due to the limited sample size it was not possible to carry out gender interactions, thus we control for gender in all models. Tables 1 to 3 show descriptive information with regard to the social and schooling control variables in our analysis. In spite of some cross-national variations, the descriptive data highlights a comparative social vulnerability of first- and second-generation migrant students. In all three countries, even amongst youths who have obtained a higher education qualification certificate, those with no migrant background have better educated parents, a more advantageous socio-economic background, and better scholastic performances. In France and Germany, youths with a migrant background also have slightly lower educational/social status aspirations. In Switzerland, despite their relative disadvantaged starting position, students with a migrant background have higher future job aspirations when compared to students with two Swiss parents.

2 The category Albania/Kosovo includes both youth from Albania and Kosovo, the two countries having been clustered together in the TREE data. Accordingly the category of former Yugoslavia excludes youth from Kosovo. 
Table 1 Social and schooling characteristics in upper secondary school of students for Switzerland

\begin{tabular}{lrrr}
\hline Country of parental origin & $\begin{array}{r}\text { Western and } \\
\text { Southern Europe }\end{array}$ & $\begin{array}{r}\text { Turkey, former Yugoslavia, } \\
\text { Albania/Kosovo, Portugal }\end{array}$ & Switzerland \\
\hline Parents higher education diploma & $45 \%$ & $28 \%$ & $54 \%$ \\
Basic requirements lower secondary & $6 \%$ & $20 \%$ & $4 \%$ \\
school track & $73 \%$ & $70 \%$ & $85 \%$ \\
Above the mark (languages) & $64 \%$ & $63 \%$ & $75 \%$ \\
Above the mark (mathematics) & $77 \%$ & $62 \%$ & $90 \%$ \\
PISA reading score (above OECD average) & $69 \%$ & $75 \%$ & $65 \%$ \\
High future job aspirations & 735 & 678 & 4386 \\
N & & & \\
\hline
\end{tabular}

Source: TREE (Transition from Education to Employment) 2000.

Table 2 Socia and schooling characteristics in upper secondary school of students for France

\begin{tabular}{lrrr}
\hline Country of parental origin & North Africa & Southern Europe & France \\
\hline Parents higher education diploma & $2 \%$ & $4 \%$ & $34 \%$ \\
Belated entry in secondary school & $15 \%$ & $22 \%$ & $6 \%$ \\
Above average marks (language) & $40 \%$ & $57 \%$ & $74 \%$ \\
Above average marks (mathematics) & $33 \%$ & $53 \%$ & $73 \%$ \\
Aspirations to study in higher education & $71 \%$ & $68 \%$ & $74 \%$ \\
N & 494 & 132 & 8983 \\
\hline
\end{tabular}

Source: Students' panel of secondary school, survey 1995, 1995-2011. Electronic file (2006), produced by DEPP | INSEE, diffused by Centre Maurice Halbwachs.

Table 3 Social and schooling characteristics in upper secondary school of students for Germany

\begin{tabular}{lrrr}
\hline Country of parental origin & Eastern Europe & Turkey & Germany \\
\hline Parents higher education diploma & $33 \%$ & $12 \%$ & $45 \%$ \\
Secondary school track other than Gymnasium & $62 \%$ & $81 \%$ & $40 \%$ \\
Above average marks & $23 \%$ & $17 \%$ & $51 \%$ \\
Importance of achieving a high social status (from 1 & 4.4 & 4.9 & 4.0 \\
"unimportant" to 6 "very important," average) & & & \\
N & 100 & 86 & 11868 \\
\hline
\end{tabular}

Source: DZHW (Studienberechtigten-Panel) 2002. 
We apply a broad definition of higher education (HE) in our analysis. It includes that includes various educational programmes that classify as level 5A (academic) according to UNESCO's International Standard Classification of Education 1997. In both Switzerland and Germany, higher education includes universities, universities of applied science, and teacher education (excluding higher vocational education and training). French higher education covers universities, short vocational tertiary programmes (institut universitaire de technologie - IUT / section de technicien supérieur - STS), and other types of HE programmes. ${ }^{3}$ We do not control for the different higher education tracks of each country due to sample size of the migrant youths and also in an effort to keep our cross-national analysis relatively easy to interpret.

On the upper-secondary level, we make the distinction between academic and vocational routes to higher education. Table 4 gives an overview of the possible tracks between secondary school and HE (academic track, vocational track and noneligible track for $\mathrm{HE}$ ) in relationship to country specific type of upper-secondary qualifications. As already mentioned, our analysis only covers youths who have acquired a qualification that makes them eligible for higher education.

For our analysis, we distinguish between three different pathways: (1) academic pathways to higher education; (2) vocational pathways to higher education; and

Table 4

Educational pathways and higher education qualification certificates by country

\begin{tabular}{|c|c|c|c|}
\hline & (1) Academic & (2) Vocational & $\begin{array}{l}\text { (3) Non-eligible for } \\
\text { higher education }\end{array}$ \\
\hline Switzerland & $\begin{array}{l}\text { General baccalaureate } \\
\text { (Matura) } \rightarrow \text { univer- } \\
\text { sity/SFIT, university of } \\
\text { teacher education }\end{array}$ & $\begin{array}{l}\text { Vocational baccalaureate (Berufmaturität, } \\
\text { Fachmaturität) } \rightarrow \text { university of applied } \\
\text { sciences, university of teacher education }\end{array}$ & \multirow{3}{*}{$\begin{array}{l}\text { Academic or voca- } \\
\text { tional certificate } \rightarrow \\
\text { Non HE qualifica- } \\
\text { tion } \\
\text { (Labour market or } \\
\text { other). e. g. VET in } \\
\text { Switzerland and } \\
\text { Germany, CAP/BEP } \\
\text { in France }\end{array}$} \\
\hline France & $\begin{array}{l}\text { Baccalauréat général } \\
\rightarrow \text { university, Prep. } \\
\text { Schools, IUT, BTS }\end{array}$ & $\begin{array}{l}\text { Baccalauréat technologique and profes- } \\
\text { sionnel } \rightarrow \text { (university, IUT, STS) }\end{array}$ & \\
\hline Germany & Abitur $\rightarrow$ university & $\begin{array}{l}\text { Hochschulzugangsberechtigung, } \\
\text { Fachgebundene Hochschulreife, } \\
\text { Fachhochschulreife, (theoretischer Teil der } \\
\text { Fachhochschulreife) } \rightarrow \text { university of ap- } \\
\text { plied sciences }\end{array}$ & \\
\hline
\end{tabular}

Notes: SFIT = Swiss Federal Institute of Technology; HE = Higher education; VET = Vocational education and training; $C A P=$ Certificat d'aptitude professionnelle; $B E P=$ Brevet d'études professionnelles; IUT=Institut universitaire de technologie; BTS = Brevet de Technicien Supérieur; STS = Section de technicien supérieur.

3 Preparatory schools for business and engineering, art, architecture, nursing, and social work. 
Table $5 \quad$ Educational pathways to higher education by country and migrant background

\begin{tabular}{|c|c|c|c|}
\hline & Migrant group I & Migrant group II & $\begin{array}{l}\text { No migrant } \\
\text { background }\end{array}$ \\
\hline \multicolumn{4}{|c|}{ Pathway 1: Academic pathway to higher education } \\
\hline Switzerland & $\begin{array}{l}\text { Western and Southern } \\
\text { European } 60 \%\end{array}$ & $\begin{array}{l}\text { Turks, former Yugoslavs, Albanian/ } \\
\text { Kosovan, Portuguese } 25 \%\end{array}$ & Swiss $43 \%$ \\
\hline France & Southern European 31\% & North African $25 \%$ & French $47 \%$ \\
\hline Germany & Eastern European 55\% & Turks 30\% & German $58 \%$ \\
\hline \multicolumn{4}{|c|}{ Pathway 2: Vocational pathway to higher education } \\
\hline Switzerland & $\begin{array}{l}\text { Western and Southern } \\
\text { European } 7 \%\end{array}$ & $\begin{array}{l}\text { Turks, former Yugoslavs, Albanian/ } \\
\text { Kosovan, Portuguese } 24 \%\end{array}$ & Swiss $21 \%$ \\
\hline France & Southern European 35\% & North African $41 \%$ & French $27 \%$ \\
\hline Germany & Eastern European 19\% & Turks $42 \%$ & German $14 \%$ \\
\hline \multicolumn{4}{|c|}{ Pathway 3: Non-tertiary pathway with higher education entrance qualification } \\
\hline Switzerland & $\begin{array}{l}\text { Western and Southern } \\
\text { European } 33 \%\end{array}$ & $\begin{array}{l}\text { Turks, former Yugoslavs, Albanian/ } \\
\text { Kosovan, Portuguese } 51 \%\end{array}$ & Swiss 36\% \\
\hline France & Southern European 34\% & North African $34 \%$ & French $26 \%$ \\
\hline Germany & Eastern European 26\% & Turks $28 \%$ & German 28\% \\
\hline
\end{tabular}

Source: Transition from Education to Employment (Switzerland), Students' panel of secondary school (France), Studienberechtigten-Panel (Germany).

(3) non-tertiary pathways despite available HE entry qualification (either academic or vocational).

Table 5 shows the distributions of students with and without a migrant background (first- and second-generation) across our three defined educational pathways in Switzerland, France, and Germany according to our data. As we exclude young people without higher education entry certificate $e^{4}$ this makes our analyses very selective when it comes to educational attainment. According to official education statistics, the ratio of youth without higher education entry certificate amounts to 66\% in Switzerland, 26\% in France and 50\% in Germany. In each of the countries, students with a migrant background are considerably overrepresented among those without a higher education entry certificate.

In France, the percentage of second-generation youths from North Africa and Southern Europe that access higher education via the vocational pathway (Pathway $2)$ is higher $(41 \%$ and $35 \%)$ than for French youths $(27 \%)$. We have a similar pat-

4 i. e. those that complete upper secondary education with an occupational diploma and those who drop out of secondary education or enter the labour market directly after leaving compulsory education. 
tern in Germany, especially for the Turkish second-generation (42\%, compared to $14 \%$ for Germans with no migrant background). In Switzerland, second-generation youths are not overrepresented in the vocational route to higher education (however, 24\% of Turkish, former Yugoslav, Albanian/Kosovan, and Portuguese students versus only $7 \%$ for Western and Southern European students follow this route, compared to $21 \%$ of Swiss students without a migrant background). In Switzerland $60 \%$ of Western and Southern Europeans access higher education via the academic route (compared to $43 \%$ for Swiss natives), whereas in all the other migrant groups across the three countries (except Eastern European in Germany), the access to higher education via the academic pathway is inferior to that of the non-migrant group (generally around 20-30\% less). Moreover, in addition, of those students with HE entry qualifications, Turkish, former Yugoslav, Albanian/Kosovan, and Portuguese youth in Switzerland, and North African and Southern European students in France, are all more likely to forgo enrolment into higher education when compared to students with two native-born parents (around 10-15\% more).

\section{Multivariate analysis}

We perform a series of multinomial regressions with educational pathways as our outcome variable and a student's migrant background as our main independent variable. We further control for gender (in all three models), student's ability, cultural- and economic capital of the student's family (in model 2 and model 3), and future educational or job/social status aspirations (in model 3). By doing so, we wish to identify if there remains a residual effect of country of origin, i. e. if having a migrant background increases the likelihood of following a certain educational pathway. In total, we estimate three consecutive multinomial logistic regression models per country. We calculated average marginal effects for our regression estimates to limit potential biases due to unobserved heterogeneity and to make our results more comparable across models and countries (Mood 2010). In our first regression model, we include only the student's migrant background, generation (first-generation as reference in order to estimate specific difference for secondgeneration), and gender, thereby giving equivalent results for migrant background. In model 2, we introduce additional controls for previous schooling (previous school performances, ability scores, and other school variables). In model 3, we add future aspirations and parental education. Table 6 shows for each country and regression model, the average marginal effects of having a migrant background on being in a respective educational pathway.

In Switzerland, second-generation immigrants from Western and Southern European origins have an 18-percentage point higher probability of accessing higher education via the academic pathway compared to their Swiss peers. Turks, former 
Yugoslavs, Albanian/Kosovan, and Portuguese as a group exhibit an 18-percentage point lower probability (pathway 1 , model 1 ). Additional analysis show that the latter outcome is mainly due to the Portuguese who, if analysed separately, show a 27-percentage point lower probability of using the traditional route compared to the Swiss. In the vocational route to higher education, Western and Southern Europeans show a 15-percentage point lower probability compared to the Swiss peers. For Turks, former Yugoslavs, Albanian/Kosovan, and Portuguese, we find no difference to the Swiss.

Previous schooling and social characteristics partly explain the relative low representation of Turkish, former Yugoslav, Albanian/Kosovan, and Portuguese students in the academic track (pathway 1, models 2 and 3). Our full model, however, does not explain why Western and Southern Europeans have a higher probability of being in the traditional academic track to higher education compared to Swiss students without a migrant background (the predicted difference in probability remains quite high at $20 \%$ ).

In France, North African and Southern European youths have a decreased probability (21 and 14 percentage points respectively) of entering higher education via the traditional academic route (pathway 1 , model 1 ). However, when controlling for school performance and social factors (models 2 and 3), these differences disappear. In the vocational route to higher education, we observe a higher probability for students with a migrant background (18\% and $10 \%$ respectively) (pathway 2 , model 1). As with the first pathway, these differences decrease and are no longer statistically different from zero when controlling for schooling and social characteristics (pathway 2, models 2 and 3). Finally, in our full model, North African youths have an overall higher probability of using their entry certificates to enrol into higher education compared to French students without a migrant background (6\%).

In Germany, Turkish students have a $22 \%$ lower probability of entering higher education via the traditional academic route when compared to their German counterparts (pathway 1, model 1). These differences again disappear when controlling for school performance and social factors (models 2 and 3). However, when we look at the vocational route to higher education, we observe a $17 \%$ higher probability for Turkish students (pathway 2, model 1). Even when controlling for schooling and social characteristics, there remains a higher probability (7\%) of entering higher education via the vocational route (pathway 2, models 2 and 3).

Contrary to Turkish students, Eastern Europeans do not have a lower probability of entering higher education via the traditional academic route (pathway 1 , model 1). If we control for previous schooling and social characteristics (models 2 and 3), we even observe a 9\% increased probability of choosing this track when compared to German students without a migrant background. We find no differences between Eastern Europeans and German students with no migrant background in their overall probability of being in the vocational route to higher education 
Table $6 \quad$ Multinomial models of education pathways (average marginal effects)

\begin{tabular}{|c|c|c|c|c|c|c|}
\hline \multirow[t]{2}{*}{ Educational pathway } & \multicolumn{2}{|c|}{ Switzerland } & \multicolumn{2}{|c|}{ Germany } & \multicolumn{2}{|c|}{ France } \\
\hline & $\begin{array}{c}\text { Western and } \\
\text { Southern } \\
\text { European }\end{array}$ & $\begin{array}{r}\text { Turks, former } \\
\text { Yugoslavs, Alba- } \\
\text { nian/Kosovan, } \\
\text { Portuguese }\end{array}$ & Turks & $\begin{array}{r}\text { Eastern } \\
\text { European }\end{array}$ & $\begin{array}{l}\text { Southern } \\
\text { European }\end{array}$ & $\begin{array}{r}\text { North } \\
\text { African }\end{array}$ \\
\hline \multicolumn{7}{|c|}{ 1: Academic Bac. $\rightarrow$ Higher education } \\
\hline $\begin{array}{l}\text { Model 1: 2nd generation- } \\
\text { migrant / gender }\end{array}$ & $\begin{array}{l}0.178^{* *} \\
(0.076)\end{array}$ & $\begin{array}{c}-0.184^{*} \\
(0.074)\end{array}$ & $\begin{array}{l}-0.222^{* * *} \\
(0.063)\end{array}$ & $\begin{array}{l}-0.033 \\
(0.056)\end{array}$ & $\begin{array}{l}-0.141^{* *} \\
(0.047)\end{array}$ & $\begin{array}{l}-0.212^{* * *} \\
(0.024)\end{array}$ \\
\hline $\begin{array}{l}\text { Model 2: lower secondary } \\
\text { school /ability }\end{array}$ & $\begin{array}{l}0.196^{*} \\
(0.080)\end{array}$ & $\begin{array}{l}-0.116 \\
(0.082)\end{array}$ & $\begin{array}{l}-0.007 \\
(0.053)\end{array}$ & $\begin{array}{r}0.087^{+} \\
(0.048)\end{array}$ & $\begin{array}{l}-0.041 \\
(0.049)\end{array}$ & $\begin{array}{l}-0.031 \\
(0.028)\end{array}$ \\
\hline Model 3: SES / aspirations & $\begin{array}{l}0.200^{* *} \\
(0.074)\end{array}$ & $\begin{array}{l}-0.073 \\
(0.083)\end{array}$ & $\begin{array}{l}-0.026 \\
(0.052)\end{array}$ & $\begin{array}{l}0.095^{*} \\
(0.047)\end{array}$ & $\begin{array}{c}0.020 \\
(0.044)\end{array}$ & $\begin{array}{c}0.030 \\
(0.026)\end{array}$ \\
\hline \multicolumn{7}{|c|}{ 2: Vocational Bac. $\rightarrow$ Higher education } \\
\hline $\begin{array}{l}\text { Model 1: 2nd generation- } \\
\text { migrant / gender }\end{array}$ & $\begin{array}{l}-0.145^{* * *} \\
(0.028)\end{array}$ & $\begin{array}{c}0.034 \\
(0.099)\end{array}$ & $\begin{array}{l}0.169^{* * *} \\
(0.028)\end{array}$ & $\begin{array}{c}0.039 \\
(0.034)\end{array}$ & $\begin{array}{c}0.095 \\
(0.049)\end{array}$ & $\begin{array}{l}0.175^{* * *} \\
(0.027)\end{array}$ \\
\hline $\begin{array}{l}\text { Model 2: lower secondary } \\
\text { school / ability }\end{array}$ & $\begin{array}{l}-0.150^{* * *} \\
(0.029)\end{array}$ & $\begin{array}{c}0.014 \\
(0.086)\end{array}$ & $\begin{array}{l}0.071^{* *} \\
(0.023)\end{array}$ & $\begin{array}{l}-0.007 \\
(0.028)\end{array}$ & $\begin{array}{c}0.052 \\
(0.046)\end{array}$ & $\begin{array}{l}0.089^{* *} \\
(0.026)\end{array}$ \\
\hline Model 3: SES / aspirations & $\begin{array}{l}-0.149^{* * *} \\
(0.029)\end{array}$ & $\begin{array}{c}0.025 \\
(0.084)\end{array}$ & $\begin{array}{l}0.061^{* *} \\
(0.023)\end{array}$ & $\begin{array}{l}-0.010 \\
(0.028)\end{array}$ & $\begin{array}{c}0.013 \\
(0.041)\end{array}$ & $\begin{array}{c}0.035 \\
(0.023)\end{array}$ \\
\hline \multicolumn{7}{|c|}{ 3: All Bac. $\rightarrow$ No Higher education } \\
\hline $\begin{array}{l}\text { Model 1: 2nd generation- } \\
\text { migrant / gender }\end{array}$ & $\begin{array}{l}-0.032 \\
(0.076)\end{array}$ & $\begin{array}{c}0.150 \\
(0.107)\end{array}$ & $\begin{array}{c}0.051 \\
(0.056)\end{array}$ & $\begin{array}{l}-0.007 \\
(0.052)\end{array}$ & $\begin{array}{c}0.046 \\
(0.045)\end{array}$ & $\begin{array}{c}0.037 \\
(0.024)\end{array}$ \\
\hline $\begin{array}{l}\text { Model 2: lower secondary } \\
\text { school / ability }\end{array}$ & $\begin{array}{l}-0.046 \\
(0.080)\end{array}$ & $\begin{array}{c}0.102 \\
(0.093)\end{array}$ & $\begin{array}{l}-0.064 \\
(0.053)\end{array}$ & $\begin{array}{l}-0.079 \\
(0.050)\end{array}$ & $\begin{array}{l}-0.011 \\
(0.039)\end{array}$ & $\begin{array}{l}-0.057^{* *} \\
(0.019)\end{array}$ \\
\hline Model 3: SES / aspirations & $\begin{array}{l}-0.050 \\
(0.076)\end{array}$ & $\begin{array}{c}0.048 \\
(0.088)\end{array}$ & $\begin{array}{r}-0.087^{+} \\
(0.052)\end{array}$ & $\begin{array}{r}-0.085^{+} \\
(0.049)\end{array}$ & $\begin{array}{l}-0.034 \\
(0.034)\end{array}$ & $\begin{array}{l}-0.065^{* * *} \\
(0.017)\end{array}$ \\
\hline
\end{tabular}

${ }^{* * *} p \leq 0.001,{ }^{* *} p \leq 0.01,{ }^{*} p \leq 0.05,{ }^{*} p \leq 0.10$ (standard errors in parentheses).

Psuedo $R^{2}$ for models $1-3 ;$ FR $(0.016 ; 0.105 ; 0.166)$, DE $(0.017 ; 0.219 ; 0.325), \mathrm{CH}(0.034 ; 0.071 ; 0.101)$.

Notes: SES = Socio-Economic Status.

Source: Transition from Education to Employment (Switzerland), Students' panel of secondary school (France), Studienberechtigten-Panel (Germany).

(pathway 2, models 1-3). If we control for school performance and social factors we find that both second-generation Turkish and Eastern European students have a slightly lower probability of using their entry qualifications to enrol for higher education (pathways 3, model 3).

Our results show that North Africans in France and Turkish students in Germany are more likely to enter higher education via the vocational route compared 
to students with two native born parents. However, schooling or social factors do not explain all these differences for Turkish students. It appears that the latter follow this track independently of their social background or characteristics. This shows strong secondary effects for Turkish youth to fulfil their aspirations through the vocational pathway once they have gone beyond the selection of early tracking. In the case of North African and Southern European second-generation youths in France, and Turkish, former Yugoslav, Albanian/Kosovan, and Portuguese youths in Switzerland, controlling for school and social factors eliminates the differences with the natives in terms of access to higher education via the academic pathway. This also illustrates the strong determinants of access to the academic pathway early on the school career. Finally, in the Swiss case, the Western and Southern Europeans access more often higher education via the academic pathway compared to native Swiss, even when controlling for previous schooling and social characteristics. This shows very strong secondary effects for this group as well as a preference for Swiss natives towards the vocational track. It seems Western and Southern Europeans realise their preference for academic rather than vocational education as a means to access higher education, whereas Turkish, former Yugoslav, Albanian/Kosovan, and Portuguese students cannot fulfil such preferences, due to the lack of the required academic skills and certificates at lower secondary level. Rather, they make use of vocational education in order to fulfil their aspirations, as Glauser (2015) has confirmed based on a more recent student cohort.

\section{Conclusion}

This article attempts to determine how institutional settings in the three countries influence access to higher education for second-generation immigrant students, and whether second-generation students use similar pathways to higher education in the three countries as students without a migrant background. Relatively newer vocational pathways to higher education do seem to benefit some immigrant students and allow them to compensate for their underrepresentation in the traditional academic tracks to higher education.

The democratisation and vocationalisation of the French education system including the development of the vocational baccalauréat, enables youths from North African background to access higher education. Our analysis shows that this is also the case for Southern European youth in France. Similarly, in Germany, Turkish students seem to especially benefit from the provision of additional entrance facilities to higher education as provided by the Fachabitur (vocational baccalaureate). These results are in line with other studies that have shown that the provision of so called "second-chances" to attain a higher education entrance certificate (via the vocational route) contribute to reducing educational inequalities between natives 
and Turkish youth within secondary stage (Burkhart et al. 2011). In Switzerland, students from Turkish, former Yugoslav, Albanian/Kosovan, and Portuguese origin show a similar pattern as the Swiss in using the two pathways to higher education, whereas Western and Southern European second-generation youths clearly prefer the academic track compared to the former. This being said, the new vocational track to higher education turns out to be important for the Turks, former Yugoslavs, Albanian/ Kosovan, and Portuguese. As an earlier study (Murdoch et al. 2014) has shown this track is difficult to access especially for Turkish and former Yugoslav youth. Our result point to the importance of promoting more school-based vocational tracks to higher education, in order to avoid existing barriers in access to company based VET caused by employer discrimination (Seibert et al. 2009).

Moreover, Eastern European youths in Germany, and particularly Western and Southern European youths in Switzerland are overrepresented in the traditional route to higher education when controlled for previous schooling and social characteristics. In addition, once we control for lower secondary school type, school performance, parental education, and aspirations, students with a North African background are more likely to use their entry credentials to access higher education, compared to French students with no migrant background. The same holds true for Turkish and Eastern European students in Germany. Our results confirm recent findings by Vanholffelen (2013) that immigrant children in France are more likely to obtain the baccalauréat when their social and schooling characteristics are controlled for. The higher probability of obtaining a baccalauréat for immigrant youths reflects a strong ambition (Griga et al. 2013). For Switzerland, Picot (2012) concludes that once school performance and lower-secondary track are taken into account, the lower probability of accessing higher education for immigrant students disappears. These findings confirm the fact that inequalities in higher education between students with and without a migrant background stem in large part from early disadvantages during primary and lower secondary schooling. They need first of all to be tackled at this level, rather than at the crossroads at the end of upper secondary education.

Future comparative research should look at the inequalities that first- and second-generation youths face within higher education, with a shift from quantitative to qualitative inequalities (Arum et al. 2007; Duru-Bellat et al. 2008).

\section{References}

Arum, Richard, Adam Gamoran, and Yossi Shavit. 2007. More Inclusion Than Diversion: Expansion, Differentiation, and Market Structure in Higher Education. Pp. 1-35 in Stratification in Higher Education: A Comparative Study, edited by Yossi Shavit, Richard Arum, and Adam Gamoran. Stanford: Stanford University Press.

BAMF (Bundesamt für Migration und Flüchtlinge). 2008. Schulische Bildung von Migranten in Deutschland. Working Paper der Forschungsgruppe des Bundesamtes 13, https://www.bamf.del 
SharedDocs/Anlagen/DE/Publikationen/WorkingPapers/wp13-schulische-bildung.pdf? blob=publicationFile (01.04.2015).

Becker, Rolf. 2011. Integration von Migranten durch Bildung und Ausbildung - theoretische Erklärungen und empirische Befunde. Pp. 11-36 in Integration durch Bildung. Bildungserwerb von jungen Migranten in Deutschland, edited by Rolf Becker. Wiesbaden: VS Verlag für Sozialwissenschaften.

Becker, Rolf, Franziska Jäpel, and Michael Beck. 2013. Diskriminierung durch Lehrpersonen oder herkunftsbedingte Nachteile von Migranten im Deutschschweizer Schulsystem? Swiss Journal of Sociology 39(3): 517-549.

Bol, Thijs, and Herman G. Van de Werfhorst. 2013. Educational Systems and the Trade-Off between Labor Market Allocation and Equality of Educational Opportunity. Comparative Education Review 57(2): 285-308.

Boudon, Raymond. 1974. Education, Opportunity, and Social Inequality. New York: Wiley.

Bouvier, Gérard, and Yves Breem. 2014. Démographie des descendants d'immigrés. Infos migrations 66. Paris: Ministère de l'intérieur.

Brinbaum, Yaël, and Hector Cebolla-Boado. 2007. The School Careers of Ethnic Minority Youth in France: Success or Disillusion? Ethnicities 7(3): 445-474.

Brinbaum, Yaël, and Christine Guégnard. 2013. Choices and Enrollments in French Secondary and Higher Education: Tensions and Repercussions for Second-Generation Immigrants. Comparative Education Review 57(3) - Special Issue on Fair Access to Higher Education: 481-502.

Buchholz, Sandra, Christian Imdorf, Sandra Hupka-Brunner, and Hans-Peter Blossfeld. 2012. Sind leistungsschwache Jugendliche tatsächlich nicht ausbildungsfähig? Eine Längsschnittanalyse zur beruflichen Qualifizierung von Jugendlichen mit geringen kognitiven Kompetenzen im Nachbarland Schweiz. Kölner Zeitschrift für Soziologie und Sozialpsychologie 64(4): 701-727.

Burkhart, Simone, Ulrich Heublein, and Johanna Wank. 2011. Bildungsinländer 2011.

Bonn: DAAD, http://www.dzhw.eu/pdf/21/daad_bildungsinlaender_2011.pdf (01.10.2014).

Crul, Maurice, Schneider Jens, and Lelie Frans. 2012. The European Second Generation Compared. Does the Integration Context Matter? IMISCOE Research. Amsterdam: Amsterdam University Press.

Duru-Bellat, Marie, Annick Kieffer, and David Reimer. 2008. Patterns of Social Inequalities. Access to Higher Education in France and Germany. International Journal of Comparative Sociology 49: 347-368.

Fibbi, Rosita, Mathias Lerch, and Philippe Wanner. 2011. School Qualifications of Children of Immigrant Descent in Switzerland. Pp. 110-134 in The Next Generation: Immigrant Youth in a Comparative Perspective, edited by Richard Alba and Mary Waters. New York: New York University Press.

FSO (Federal Statistical Office). 2008. Ausländerinnen und Ausländer in der Schweiz. Bericht 2008. Neuchâtel: FSO.

Glauser, David. 2015. Berufsausbildung oder Allgemeinbildung? Soziale Ungleichheiten beim Übergang in die Sekundarstufe II in der Schweiz. Wiesbaden: Springer VS.

Griga, Dorit. 2014. Participation in Higher Education of Youths with a Migrant Background in Switzerland. Swiss Journal of Sociology 40(3): 379-400.

Griga, Dorit, and Andreas Hadjar. 2014. Migrant Background and Higher Education Participation in Europe: The Effect of the Educational Systems. European Sociological Review 30(3): 275-286.

Griga, Dorit, Andreas Hadjar, and Rolf Becker. 2013. Bildungsungleichheiten beim Hochschulzugang nach Geschlecht und Migrationshintergrund: Befunde aus der Schweiz und aus Frankreich. Pp. 270-293 in Geschlecht, Migrationshintergrund und Bildungserfolg, edited by Andreas Hadjar and Sandra Hupka-Brunner. Weinheim: Beltz Juventa Verlag.

Heath, Anthony F., and Yaël Brinbaum. 2014. Unequal Attainments. Ethnic Educational Inequalities in Ten Western Countries. Proceedings of the British Academy 196. Oxford: Oxford University Press. 
Heath, Anthony F., Catherine Rothon, and Elina Kilpi. 2008. The Second Generation in Western Europe: Education, Unemployment, and Occupational Attainment. Annual Review of Sociology 34: 211-235.

Hossmann, Iris, and Margret Karsch. 2011. Germany's Integration Politics. Berlin: Berlin-Institut für Bevölkerung und Entwicklung, http://www.berlin-institut.org/fileadmin/user_upload/handbuch_texte/pdf_Hossmann_Karsch_Germanys_Integration_Politics.pdf (17.03.2015).

Hupka, Sandra, and Barbara Stalder. 2011. Jeunes migrantes et migrants à la charnière du secondaire I et du secondaire II. Pp. 183-200 in Transitionen im Jugendalter: Ergebnisse der Schweizer Längsschnittstudie TREE, edited by Max Bergman, Sandra Hupka-Brunner, Anna Keller, Thomas Meyer, and Barbara Stalder. Zürich: Seismo.

Kao, Grace, and Marta Tienda. 1995. Optimism and Achievement: The Educational Performance of Immigrant Youth. Social Science Quarterly 76(1): 1-19.

Kao, Grace, and Marta Tienda. 1998. Educational Aspirations of Minority Youth. American Journal of Education 106(3): 349-384.

Kristen, Cornelia, and Jörg Dollmann. 2010. Sekundäre Effekte der ethnischen Herkunft: Kinder aus türkischen Familien am ersten Bildungsübergang. Pp. 117-144 in Vom Kindergarten bis zur Hochschule. Die Generierung von ethnischen und sozialen Disparitäten in der Bildungsbiographie, edited by Birgit Becker and David Reimer. Wiesbaden: VS Verlag für Sozialwissenschaften.

Mood, Carina. 2010. Logistic Regression: Why We Cannot Do What We Think We Can Do, and What We Can Do About It. European Sociological Review 26(1): 67-82.

Murdoch, Jake, Christine Guégnard, Maarten Koomen, Christian Imdorf, and Sandra Hupka-Brunner. 2014. Pathways to Higher Education in France and Switzerland. Do Vocational Tracks Facilitate Access to Higher Education for Immigrant Students? Pp. 149-169 in Higher Education in Societies - A Multi Scale Perspective, edited by Gaële Goastellec and France Picard. Rotterdam: Sense publishers.

Nikolai, Rita, and Christian Ebner. 2012. The Link between Vocational Training and Higher Education in Switzerland, Austria, and Germany. Pp. 234-258 in The Political Economy of Collective Skill Formation, edited by Marius R. Busemeyer and Christine Trampusch. Oxford: Oxford University Press.

OECD (Organisation for Economic Co-operation and Development). 2014. Education at a Glance. Paris: OECD Publishing.

Pape, Ulrike. 2010. Deutschland: Immer mehr Menschen mit Migrationshintergrund. Newsletter Migration \& Bevölkerung 7/10, http://www.migration-info.de/artikel/2010-09-13/deutschlandimmer-mehr-menschen-migrationshintergrund (17.03.2015).

Picot, Garnett. 2012. Immigrant Status and Secondary School Performance as Determinants of PostSecondary Participation: A Comparison of Canada and Switzerland. OECD Education Working Papers 77. Paris: OECD Publishing.

SCCRE (Swiss Coordination Centre for Research in Education) (Ed.). 2011. Swiss Education Report 2010. Aarau: Swiss Coordination Centre for Research in Education.

Seibert, Holger, Sandra Hupka-Brunner, and Christian Imdorf. 2009. Wie Ausbildungssysteme Chancen verteilen: Berufsbildungschancen und ethnische Herkunft in Deutschland und der Schweiz unter Berücksichtigung des regionalen Verhältnisses von betrieblichen und schulischen Ausbildungen. Kölner Zeitschrift für Soziologie und Sozialpsychologie 61(4): 495-620.

Statistisches Bundesamt. 2015. Migrationshintergrund. Wiesbaden: Statistisches Bundesamt,

https://www.destatis.de/DE/ZahlenFakten/GesellschaftStaat/Bevoelkerung/MigrationIntegration/Migrationshintergrund/Migrationshintergrund.html (17.03.2015).

Van de Werfhorst, Hermann G., and Frank Van Tubergen. 2007. Ethnicity, Schooling, and Merit in the Netherlands. Ethnicities 3: 416-444.

Vanhoffelen, Aude. 2013. Les bacheliers du panel 1995: Evolution et analyse des parcours. Note d'information 10.13. Paris: Direction de l'évaluation et de la prospective, Ministère de l'Education nationale. 


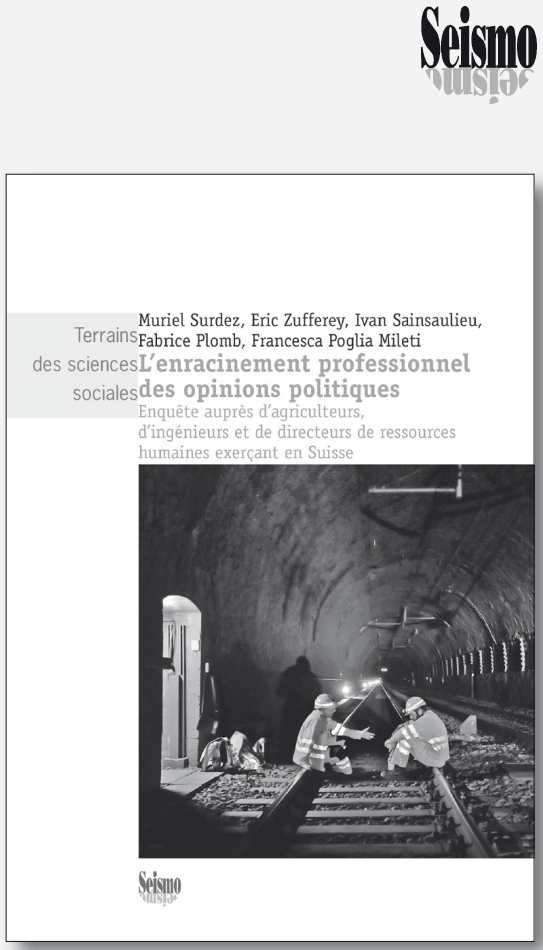

Le vécu au travail façonne-t-il aujourd'hui les représentations sociopolitiques des individus? L'enquête qualitative menée au sein de trois groupes professionnels montre que les activités professionnelles alimentent les jugements portés sur la société et la politique. Les ingénieurs conçoivent la hiérarchie sociale et les choix politiques à l'aune de leur formation scientifique, axée vers la technique ou le management. Les agriculteurs se démarquent plus ou moins des loyautés politiques locales selon le type d'agriculture qu'ils privilégient pour assurer leur futur. En politique comme dans leur profession, les DRH valorisent une position de surplomb synthétisant des points de vue antagonistes. Comparant ces "ethos professionnels», l'ouvrage relativise les constats de dissolution des appartenances professionnelles et d'individualisation des opinions. Il examine les modalités d'organisation du travail www.editions-seismo.ch / info@editions-seismo.ch www.seismoverlag.ch / info@seismoverlag.ch

\section{Terrains des sciences sociales}

Muriel Surdez, Eric Zufferey, Ivan Sainsaulieu, Fabrice Plomb, Francesca Poglia Mileti

\section{L'enracinement professionnel des opinions politiques Enquête auprès d'agriculteurs et d'ingénieurs de ressources humaines exerçant en Suisse}

272 pages, SFr. 38.-_/Euro 35.ISBN 978-2-88351-065-4

et de concurrence, les trajectoires et les réseaux de sociabilités pour saisir les logiques de production des opinions propres à chaque groupe et leurs différenciations internes.

Muriel Surdez est professeure au Département des sciences sociales de l'Université de Fribourg. Eric Zufferey est assistant diplômé et doctorant au Département des sciences sociales de l'Université de Fribourg.

Ivan Sainsaulieu est professeur de sociologie à l'Université de Lille 1, membre du laboratoire Clersé.

Fabrice Plomb est maître d'enseignement et de recherche au Département des sciences sociales de l'Université de Fribourg.

Francesca Poglia Mileti est professeure de sociologie au Département des sciences sociales de l'Université de Fribourg. 